\title{
Science, Technology and Religion: The Exchange Between Enlightenment Europe and Imperial China
}

\author{
Robert V. Davis, Jr. \\ Independent scholar, Myrtle Beach, South Carolina, USA \\ BobDavis@alum.MIT.edu
}

Abstract: The European Enlightenment fostered a sense of progress through a delineation of universal human rights as well as through a reductionist mathematization of nature. Science, technology and religion became a form of cultural currency between Europe and Imperial China. The Jesuits bartered mathematics, geographic surveys and military technology to win religious permissions with Chinese emperors. Other Europeans were convinced ancient Chinese texts corresponded to the Old Testament. China sent to Europe a Confucian model of a social ethic that demonstrated non-Christian civic virtues. This article examines this exchange using the intercourse in science, technology and religion as the metric.

Keywords: Enlightenment; China; science; religion; Jesuits 


\section{Introduction}

The era of the European Enlightenment was one of exceptionally dynamic intellectual expansion. It was also a time of expansive colonial activity in the economic, religious and military realms. These extraterritorial activities ensured that evolving European religious values were necessarily reflected in dealings with foreign cultures. The Orient has consistently been a source of cultural images, both as extractions and reflections, of the Other. Consequently, it is possible to illuminate concepts of the Enlightenment by examining the context of the exchange between Europe and China during that era. What constructs, both material and spiritual, did the Europeans choose to export and why? Conversely, what was extracted from China and imported to Europe- either in fact or as a reflection of the imagined Other?

As a part of any transaction there must be some medium of exchange. Given the Enlightenment's concern with the rationalization of nature, it is unsurprising that science and technology became one form of currency. The Jesuits played a central role in cultural and religious interactions with China through the barter of mathematics, geographic surveys and military technology to win favor with Emperor Kangxi (康熙, 1654-1722), a perceived model of the enlightened despot. Gottfried Leibniz (1646-1716), in addition to his search for a universal scientific language, was convinced that the hexagrams of the ancient Yijing (易經) were based on a binary mathematical system that was similar to his own research results. Comparison of historical astronomical observations convinced Jesuit Father Joachim Bouvet (1656-1730) that events revealed in ancient Chinese texts corresponded to those of the Old Testament and documented an antediluvian history that was common to both cultures. China, on the other hand, sent to Europe not only technologically based constructs such as designs for furniture and gardens as well as techniques for textiles, pottery and watercolors, but also sent a Confucian model of a social ethic that epitomized potentially universal non-Christian civic virtues sought by Enlightenment Europe.

In addition to Leibniz, many of the major creative intellects from the Enlightenment and preEnlightenment at some point expressed a profound interest in Eastern philosophy. A veritable all-star roster-Michel de Montaigne (1533-1592), Nicolas Malebranche (1638-1715), Voltaire (François-Marie Arouet; 1694-1778), Montesquieu (Charles-Louis de Secondat, 1689-1755), Claude Adrien Helvétius, (1715-1771), Denis Diderot (1713-1784), Daniel Defoe (16601731), Immanuel Kant (1724-1804), and Adam Smith (1723-1790)—debated China as an alternative model to at least some aspect of Enlightenment Europe. These European thinkers perceived the Orient "not as it was, but as they badly needed it to be ... peaceful, natural and pure, lived without an intrusive church or government, and which contained only simple societies with no great distinctions of wealth or social status." ${ }^{1}$ For many, lauding a far-removed

${ }^{1}$ Dorinda Outram, The Enlightenment (Cambridge: Cambridge University Press, 2005), 51. 
utopia was an effective form of a more local social critique - a challenge to government, religion, and prevailing social mores. ${ }^{2}$ Nowhere did this dichotomous nature manifest itself more than in the Enlightenment's intellectual commerce with China.

\section{China as the oriental other}

Science and technology in the Enlightenment were, by their very natures, thought to be useful. Science brought a form of knowledge that could be applied outside of its own domain to accomplish social ends. Technology was, at its most fundamental level, a tool to accomplish a task-be it conquest, agriculture, or the measurement of time. However, during the Enlightenment, science and technology became implements of a different sort. Disembodied from their physical essences, their very concepts were employed as talismans to weaken Christianity. For Voltaire, miracles did not exist because they simply could not occur within the limits of scientific evidence. ${ }^{3}$ Yet, alternatively, science and technology were also utilized by the Jesuits as a form of barter with the heathen Chinese culture to broaden the reach of that very same Christianity.

A major preoccupation of the French philosophes was the central influence that the Christian Church had over the truth of moral and civic behavior. While the Chinese Other provided a convenient contrivance employed by Enlightenment figures to obliquely criticize both Christianity and the government, scientific rationality was the exemplar used as the metric. However, it is ironic that in attempting to impose scientific rationality as the sole method for determining truth, the philosophes were open to the same charges of doctrinal absolutism that they were directing at the Church. ${ }^{4}$

In the intellectual debates of the Enlightenment one search for an appropriate Other centered on an intellectual commerce with China. In his quest to destroy the influence of Christianity, Voltaire turned to China. ${ }^{5}$ In an oblique arabesque to Voltaire's comment about God: "if there had been no China, Voltaire would have been forced to invent one." For both those enamored and those disappointed with the Orient, the Sinophiles and Sinophobes, China

\footnotetext{
2 Walter W. Davis, "China, the Confucian Ideal, and the European Age of Enlightenment," Journal of the History of Ideas 44, no. 4 (1983): 523-48, on 523.

${ }^{3}$ Rebecca Joubin 2000, "Islam and Arabs through the Eyes of the Encyclopedie: The 'Other' as a Case of French Cultural Self-Criticism," International Journal of Middle East Studies 32, no. 2 (2000): 197217, on 197.

4 Ibid., 210.

5 Arnold H. Rowbotham, "Voltaire, Sinophile," Transactions and Proceedings of the Modern Language Association of America 47, no. 4 (1932): 1050-65, on 1060.

${ }^{6}$ Frederic Wakeman, Jr., “The Chinese Mirror: China's Developmental Experience," Proceedings of the Academy of Political Science 31, no. 1 (1973): 208-19, on 209.
} 
offered the advantages of having an ancient and civilized culture while being neither Christian nor European. Just as the shadows in Plato's cave were the Other of an imprecisely reflected real world, China emerged as a near-blank slate upon which social critiques could be written without either need of corroboration or fear of reprisal. This does not, however, mean that there was unanimity in views. Using the Other as a means of veiled criticism of Leibniz, in Candide Voltaire described Pangloss, a fictional protégé of Leibniz, as a "professor of metaphysicotheologico-cosmolo-nigology."

Use of the expression "Orientalism" first appeared in France during the 1830s. ${ }^{8}$ Yet, as a scholarly domain, its roots originated in 1312 at the Church Council of Vienne. Although Pope Clement V (1264-1314) convened the Council to formally disband the Knights Templar, as a side matter it created academic chairs in Arabic, Greek, Hebrew, and Syriac at Paris, Oxford, Bologna, Avignon, and Salamanca. ${ }^{9}$ As Edward Said has argued, the European view of the Orient had less to do with the people living in that region than it did with being a repository of the characteristics in opposition to which people in the West defined themselves. ${ }^{10}$ "The Orient is the 'Other' in relation to which people in the West establish their own identity, usually to affirm the values they exult and occasionally to lament those values they suppress." ${ }^{11}$ China was a culturally constructed prism through which European values could be refracted to please the Enlightenment eye.

For Europe, China had attractions that other cultures did not. Unlike the thousand-year war with Islam, China was at peace with Europe. Unlike India and America, it was never considered a European colony. Unlike Africa, it had an advanced culture and alluring wealth. The unique circumstance of China provided an expanded conceptual space for European fantasy. ${ }^{12}$ Yet, at the same time, there was an associated substance, no matter how poorly perceived and how inferior it might be considered compared with European achievements, that lent credence to the assertions of both the Sinophiles and Sinophobes while allowing them to retain their respective prior obsessions. ${ }^{13}$ With many of the leading Enlightenment intellects being natural scientists and mathematicians in their own rights, an important innovation of that era was the application of the scientific principles of rationality to the human sciences of government,

\footnotetext{
${ }^{7}$ Voltaire, Candide, trans. François-Marie Arouet (Mineola, NY: Dover Thrift Editions, 1991), 1.

${ }^{8}$ John James Clarke, Oriental Enlightenment: The Encounter Between Asian and Western Thought (New York: Routledge, 1997), 7.

${ }^{9}$ Edward W. Said, Orientalism (New York: Pantheon Books, 1978), 49-50.

${ }^{10}$ Ibid., 49.

${ }_{11}$ Arran E. Gare, "Understanding Oriental Cultures," Philosophy East and West 45, no. 3 (1995): 30928, on 310 .

${ }^{12}$ Ho-Fung Hung, "Orientalist Knowledge and Social Theories: China and the European Conceptions of East-West Differences from 1600 to 1900," Sociological Theory 21, no. 3 (2003): 254-80, on 255.

13 Jonathan I. Israel, Enlightenment Contested: Philosophy, Modernity, and the Emancipation of Man 16701752 (Oxford: Oxford University Press, 2006), 640.
} 
economics, and civic conduct. The coincident social constructs of anti-Christianity, proscience, and the Chinese Other provided a dynamic intellectual milieu that could be employed in often-contradictory ways as a weapon both against as well as for Christianity.

\section{Science and technology against Christianity}

When Father Matteo Ricci (1552-1610) and the lesser acknowledged Father Michele Ruggieri (1543-1607) led the first Jesuits into China in 1583, the Chinese ability to solve problems and predict outcomes was approximately equal to that of Europe and was probably slightly more advanced technologically. ${ }^{14}$ Francis Bacon's famous citing of printing, gunpowder, and the magnetic compass as being technologies that changed the course of the world were, in the cases of the magnetic compass and gunpowder, directly imported from China, and, in the case of printing, developed much earlier in China than in Europe. Although this rough technological equivalence would change drastically over the next two hundred years, Enlightenment attempts to portray China as a scientifically advanced, ethically coherent, and non-Christian culture were, therefore, not without validity. Against this backdrop, those opposed to the strictures of Christianity found an almost ideal Other to use as a metric. Not only was it technologically advanced, but Confucian ethical mores were highly developed and owed no allegiance to Christian values.

The encyclopedists, in particular, employed science and reason against religion, and were opportunistic in using images of China as a foil against Christianity. As revealed in the Bible, Christians believed that human genealogy was known and could be calibrated against a specific chronology. However, with the meticulously documented antiquity of the Chinese culture, Enlightenment figures, such as Voltaire, could use contradictions from the historical Chinese records to challenge what was becoming an increasingly questionable Christian orthodoxy. The antiquity of Chinese civilization and the ability to scientifically compare Chinese historical records with biblical accounts ensured that the chronology of the New Testament, and some of the Old, would be called into question. ${ }^{15}$ Oddly, the Catholic Church, through Jesuit reports home from China, improbably provided the initial evidence of biblical inaccuracy.

One issue concerned biblical accounts of the Flood. According to Chinese legend, Fuxi (伏 羲), who was believed to have ruled in 2952 BCE, was the direct ancestor of all modern Chinese. However, Irish Bishop James Ussher's (1581-1656) then-popular biblical chronology supported dates of $4004 \mathrm{BCE}$ for the creation and 2348 BCE for Noah and the flood. "But if

${ }^{14}$ Franklin Perkins, Leibniz and China: A Commerce of Light (Cambridge: Cambridge University Press, 2004), 14.

15 Donald F. Lach, "China and the Era of the Enlightenment," The Journal of Modern History 14, no. 2 (1942): 209-23, on 217. 
Fuxi had truly reigned over six hundred years earlier [than Noah], and there were no breaks of succession to the throne, then Noah could not be the universal patriarch." ${ }^{16}$ How then could the accounts of Fuxi be reconciled with biblical accounts of Noah? One creative explanation which glossed over the chronological sequence was that Fuxi was the son or grandson of Noah. Another explanation was that Chinese historical records documented a large flood around the time of Fuxi; that explanation, however, did not reveal who would have been around to create the Chinese records if everyone was on the ark. Another possibility was that the Flood only covered the Jewish homeland. ${ }^{17}$

The importance of scientific corroboration using Chinese records was important to all these efforts. Jean-Gaptiste Grosier (1743-1823) commented that: "The scholar Laplace has rendered splendid homage to the ancient [Chinese] treatises on astronomy which he considers to be older than those of any other civilization. 'Of all the ancient peoples,' he says, 'the Chinese have the most ancient records on the science of astronomy'." ${ }^{18}$ While later research into architecture, bronze castings, and literature show that Chinese civilization as an integrated culture did not develop until, at the earliest, a thousand years after Ussher dated the flood, Leibniz was not aware of this, and he and other Sinophiles accepted the earlier Chinese dates in their thinking. ${ }^{19}$

Another issue was the Chinese language. Its antiquity and continuity were possibly explained by declaring it the Lingua Adamica, the primitive tongue of all mankind. ${ }^{20}$ This, however, did not explain how it escaped God's wrath during the Tower of Babel. George Wharton (1617-1681), an Englishman, declared Fuxi to actually be Adam. ${ }^{21}$ Finally, the antiquity of the Chinese written records themselves would seem to suggest their proximity to the creation, and that Fuxi's "knowledge of the creation must have been fresh" and that his thoughts "would have been rejected had they been false." 22 The point was not so much whether the writings were properly attributed to Fuxi or even whether or not he had ever existed. What mattered to the anti-theological arguments of the philosophes was that Chinese antiquarian records were so extensive, and that by 1740 the validity of many of these Chinese histories had been documented by mathematical verifications of eclipses noted in the Chinese annals. ${ }^{23}$ Therefore,

16 Daniel J. Cook and Henry Rosemont, introduction to Writings on China, by Gottfried Wilhelm Leibniz, trans. Daniel J. Cook and Henry Rosemont, Jr. (Chicago: Open Court, 1994), 15.

17 Israel, Enlightenment Contested, 640.

${ }_{18}$ Jean-Baptiste Grosier, The World of Ancient China, trans. Lana Castellano and Christina CampbellThomson (Geneva: Editions Minerva, 1972), 81.

19 Cook and Rosemont, introduction to Writings on China, 19.

${ }^{20}$ Hung, "Orientalist Knowledge," 258.

${ }^{21}$ Lach, "China and the Era of the Enlightenment," 217.

22 Perkins, Leibniz and China, 9.

${ }^{23}$ Lach, "China and the Era of the Enlightenment," 217. 
through a comparison with China, the ability to scientifically question some of the basic tenets of Christianity meant that all might be questioned.

Use of the Chinese Other was widespread by the philosophes — even when such usage was contradictory. For example, Voltaire is typically critical of the Bible but, in order to establish the respectability of Chinese culture, he associated its antiquity with that of the Jewish Pentateuchthe first five books of the Christian old testament. ${ }^{24}$ Malebranche considered Confucianism as a form of Spinozism - an interconnection between a singular and collective existence. ${ }^{25}$ Pierre Bayle (1646-1706), whose 1697 Dictionnaire Historique et Critique (Historical and Critical Dictionary) was influential on the later encyclopedists, was also elemental in using China's antiquity to challenge biblical chronologies, and to deny the need for Christianity to create a moral society. ${ }^{26}$

Voltaire is, perhaps, the foremost French intellect to use the Chinese Other as a negative reflection of European society. His 1756 Essai sur les moeurs et l'espirit des nations (Essay on the Customs and Spirit of Nations) was an essential instrument for Voltaire's use of Confucian values to leverage his attack on the dominant contemporaneous religious and political structures. As the purported cradle of an ancient civilization, Voltaire asserted that Chinese culture was based on rational and moral ethics and not upon the dictates of the Church and the hereditary nobility - even conjecturing that Confucianism was a form of deism based on reason and not on faith. He believed that Confucius was a rationalist philosopher-statesman not espousing religious dogma, and whose moral strictures were largely responsible for the stable and peaceful social order in China. ${ }^{27}$ Voltaire, however, must not be viewed as a neutral analyst unveiling the secrets of the Orient, but rather as an opportunistic advocate for the overthrow of the establishment alliance between the aristocracy, the state, and the church.

China, of course, was not the only society in the Orient, and the Enlightenment assault on Christianity used every weapon it could find. Pro-scientific and anti-Christian discourse was also evident in consideration of Islam as the Oriental Other. The encyclopedists depicted Islam as irrational and distinct from Arab science. In her extensive analysis of the Encyclopedie, Joubin documents the "recurring topos in Orientalist discourse of Muhammad as a false prophet, an impostor, who was entirely averse to reason and science and who took advantage of the credulity of the masses to deceive them into following his religion." ${ }^{28}$ The Arab world could make progress only to the extent that the rationality of science could prevail over the illogic of Islam.

${ }^{24}$ Rowbotham, "Voltaire, Sinophile," 1059.

${ }_{25}$ Clarke, Oriental Enlightenment, 44.

${ }^{26}$ Ibid., 44.

${ }^{27}$ Ibid., 44-5.

${ }^{28}$ Joubin, "Islam and Arabs," 200. 
In his 1721 Lettres persanes (Persian Letters), Montesquieu had the fictitious Usbek, in a letter home from Paris, endorse the virtues of reason over religious beliefs, describing western philosophers who "have not been carried up to the throne of light: neither have they heard the unutterable words, nor felt the awful approach of divine frenzy; but left to themselves, and deprived of the sacred miracles, they follow silently the footprints of human reason." 29 Montesquieu left no doubt that he believed religion to be a largely emotional and pointless endeavor, while human reason left footprints that must be imagined leading somewhere.

\section{Science and technology to support Christianity}

The Jesuits have been characterized as the shock-troops of the Catholic Counter-Reformation. Founded in 1540 and initially under Portugal's patronage, not all early Jesuit reports from the Orient were made publicly available by the Portuguese government as a matter of protecting its control of trade routes. Typical of its efficient management, in 1547 senior Jesuit official Juan Alfonso de Polanco (1517-1576) created the litterae quadrimestres, a system of worldwide reports every four-months. ${ }^{30}$ However, by the mid-seventeenth century, the Jesuits had successfully negotiated the pathways of papal and secular politics to begin to receive the patronage of the French King. This had two profound effects. First, the French monarchy was less concerned than the Portuguese about preventing publication and open discussion of the Jesuit reports, and second, Enlightenment Paris had become the focal point for European knowledge of China. ${ }^{31}$ The Jesuits, however, had as their primary concerns not only the spread of Christianity in the Orient, but also the survival of their order in Europe.

Despite the Jesuits' best efforts, the rulers of China were not interested in what seemed to them the mystical doctrines of the Christian missionaries; on the other hand, they understood well the Jesuits' useful scientific expertise and were interested in shixue (实学), that is, in "practical learning." 32 In turn, even though the Jesuits exaggerated the merits of the Chinese culture in their reports home to suit their own purposes, they genuinely viewed the Chinese as being sophisticated, and governed by a class of scholars who had created a set of moral and political principles based upon universal human reason. ${ }^{33}$

${ }^{29}$ Charles-Louis Montesquieu, Persian and Chinese Letters, trans. John Davidson (London: M. Walter Dunne, 1901), 183.

${ }^{30}$ Markus Friedrich, "Circulating and Compiling the Litterae Annuae. Towards a History of the Jesuit System of Communication," 77, no. 153 (2008), 3-39, on 7.

${ }^{31}$ Hung, "Orientalist Knowledge," 257-8.

32 Nicolas Standaert, "Christianity Shaped by the Chinese," in The Cambridge History of Christianity: Reform and Expansion 1500-1660, ed. Ronnie Po-Chia Hsia (New York: Cambridge University Press, 2007), 563.

${ }^{33}$ Clarke, Oriental Enlightenment, 40-1. 
The Jesuit hierarchy expected their missionaries in China to have mathematical training. ${ }^{34} \mathrm{By}$ the 1580s, the Jesuits had penetrated into China proper during the last decades of the besieged Ming (大明) dynasty (1368-1644). They not only successfully survived the Manchu conquest and establishment of the Qing (清朝) dynasty (1644-1911), but even managed to establish close relationships with the new emperors. Late in the Ming dynasty, the Jesuit Johann Adam Schall (1592-1666) challenged the Chinese and Muslim astronomers of the court in predicting the 1629 solar eclipse and was named director of the Qing Bureau of Astronomy when his eclipse prediction was the most accurate. ${ }^{35}$ In Oliver Goldsmith's (1728-1774) 1760 parody of this same event in A Citizen of the World, a fictional letter from Lien Chi Altangi in London to Fum Hoam, First President of the Ceremonial Academy at Pekin in China related:

\begin{abstract}
The eclipse began: the Chinese produced a most splendid apparatus, and were 15 minutes wrong; the missionary, with a single instrument, was exact to a second. This was convincing: but the court astronomers were not to be convinced; instead of acknowledging their error, they assured the Emperor that their calculations were certainly exact, but that the stranger without nails had actually bewitched the moon. "Well, then," cries the good Emperor, smiling at their ignorance, "you shall still continue to be servants of the moon, but I constitute this man her controller." 36
\end{abstract}

Inasmuch as the Manchu ruled China through military conquest, the display by Schall and other Jesuits of their scientific and technological prowess was especially impressive to the Qing emperors. Moreover, in order to control the dissemination of this technological knowledge, the imperial court and the emperors themselves were frequently engaged in direct technical discussions with the Jesuits. ${ }^{37}$ This, in return, gave the Jesuits a valuable lever to use in their efforts to spread the Christian religion. As a part of the intellectual exchange, a rare few Chinese scholars began to travel to Europe. In 1654, an unnamed Chinese scholar accompanied Jesuit Martino Martini (1614-1661) from China and met with the Dutch mathematician and orientalist Jacob Golius (1596-1667) in Leiden, Netherlands. ${ }^{38}$ As a result of this symbiotic relationship, during the early decades of the Qing dynasty the Jesuits were able to barter their technical abilities in exchange for a broad dispensation by Emperor Kangxi to proselytize their religion in China. In return, the emperor employed them as his personal physicians, and as

\footnotetext{
${ }^{34}$ Noël Golvers, "Antoine Thomas, SJ, and his Synopsis Mathematica: biography of a Jesuit mathematical textbook for the China mission," East Asian Science, Technology, and Medicine, 45 (2017): 119-83, on 121.

${ }^{35}$ Perkins, Leibniz and China, 24.

36 Oliver Goldsmith, The Citizen of the World in Persian and Chinese Letters, trans. John Davidson (London: M. Walter Dunne, 1901), 400.

${ }^{37}$ Joanna Waley-Cohen, "China and Western Technology in the Late Eighteenth Century," The American Historical Review 98, no. 5 (1993): 1525-44, on 1527.

38 Joseph Needham, Science and Civilisation in China: Introductory Orientations vol. 1. (Cambridge: Cambridge University Press, 1954), 38.
} 
teachers in such technical areas as astronomy, medicine, botany, surveying and mapping, and flood control. He had little interest in understanding their religious scriptures, but rather focused his interest on their extensive background in European science and technology. ${ }^{39}$ At Kangxi's request for more scientific expertise, in 1685 the Jesuits convinced King Louis XIV (1638-1715) of France to send a party of five additional Jesuit scientists to China including Joachim Bouvet (1656-1730) who became the personal mathematics tutor to Kangxi and his children. ${ }^{40}$ These five were "the first French Jesuit venture into the Asian mission field to circumvent Portuguese authority." ${ }^{11}$ As the relationship progressed, by 1690 Kangxi had directed the Jesuits to prepare texts in the Manchu native Tatar language on arithmetic, geometry, and philosophy for his personal educational use, and also to instruct the emperor himself four hours daily- two in the morning and two in the afternoon. ${ }^{42}$

Except for a brief thirteen-year period, from 1661 though 1799, essentially the entire period of the European Enlightenment, two extraordinarily long-lived Chinese emperors-Kangxi and his grandson Qianlong (乾隆帝, 1711-1799)—ruled China. Both rulers were active proponents of acquiring technical knowledge from the Jesuits and were, by the standards of those times, relatively tolerant of the foreign missionaries. In exchange for their technical support, in 1691 the Jesuits presented a petition to Kangxi requesting that he rescind the decree of 1669 which had restricted the missionary activities of the Jesuits and also prohibited the Chinese from becoming Christians. In 1692 Kangxi proclaimed the Edict of Toleration which permitted both proselytizing and the conversion of the Chinese. In 1703, Jesuit Father Fontaney (16431710) wrote: "by a particular disposition of Providence, God permitted the sciences of which we make a profession and in which we tried to perfect ourselves before coming to China to be that which disposed the emperor to accord us this grace; so true is this, that such devices, worldly though they may be, must not be neglected." ${ }^{43}$ Shortly thereafter, when the emperor fell ill with a fever, he was cured by the Jesuits through the use of what was called "Jesuit's bark" - more modernly known as quinine. ${ }^{44}$

The facile use of technical knowledge, however, was not only used to European advantage. Leading Chinese intellectuals, such as Minister of Rites and Catholic convert Xu Guangqi (1562-1633), believed that Jesuit knowledge could be leveraged to halt the decline in China's

${ }^{39}$ Theodore E. Treutlein, "Jesuit Missions in China during the Last Years of K'ang Hsi," The Pacific Historical Review 10, no. 4 (1941) 435-46, on 435.

${ }^{40}$ Frank J. Swetz, "Leibniz, the Yijing, and the Religious Conversion of the Chinese," Mathematics Magazine 76, no. 4 (2003) 276-91, on 278.

${ }^{41}$ Florence C. Hsia, Sojourners in a Strange Land: Jesjuites and Their Scientific Missions in Late Imperial China (Chicago: University of Chicago Press, 2009), 52.

${ }^{42}$ Treutlein, "Jesuit Missions," 438.

${ }^{43}$ Jean de Fontaney, cited in Treutlein, "Jesuit Missions," 435-46.

${ }^{44}$ Treutlein, "Jesuit Missions," 442-3. 
technical learning. ${ }^{45}$ To administer a growing Chinese empire and being military in its origins, the Qing dynasty was sensibly concerned about creating accurate maps. Consequently, Kangxi convinced the Jesuits to conduct a geographical survey of his entire empire that took ten years to complete. Even though the Chinese already had substantial expertise in cartography, Kangxi recognized that the superior European astronomical skills, which were largely analogous to those required for surveying land, would translate into more accurate maps. ${ }^{46}$ The Jesuits once again complied with the imperial request and finished what was their single largest technical undertaking in China by publishing in 1718, in Peking, an atlas of the entire Chinese empire. ${ }^{47}$

Another large technological undertaking for the Jesuits was to improve Chinese cannon manufacturing and operation. As a testament to the Jesuits' facile political skills, they first provided such support to the failing Ming dynasty in the defense of Peking and then, in turn, supplied technical support to the Qing artillery after their victory to help suppress the residual Ming rebellion. The Chinese had invented gunpowder around the tenth century that had then spread to Europe by the thirteenth century. It was in the warring nations of Europe, not China, that rapid advances were made in the technological development and deployment of artillery. By the early 1600s, Portuguese experts were overseeing canon production in Macau as well as advising the Ming dynasty in its attempt to repel the Manchu invasion from the north. During the transition period from Ming to Manchu rule, first Adam Schall (1592-1666) and then Ferdinand Verbiest (1623-1688) served as head of the Imperial Board of Astronomy, the principal scientific advisor to the emperor, and the agent for the production of canon-not only for the failing Ming dynasty, but also for the victorious Manchu and what became the Qing dynasty. Verbiest's foundry, which produced almost 500 bronze and cast-iron artillery pieces over a 15-year period, operated after his death with his designs still being used in 1839 at the time of the opium war. ${ }^{48}$ Despite Jesuit Verbiest's un-Christian-like activities as a cannon manufacturer, Pope Innocent XI, in 1681 publicly praised him for "having used the profane science for the safety of the people in the advancement of the Faith." ${ }^{49}$

Kangxi was not the only Chinese emperor to agree to the unofficial barter of technology for religious access. Qianlong, equally long-lived as a ruler, echoed his grandfather's interests in European science and technology and "showed an almost childish interest in all kinds of mechanical things." ${ }^{50}$ At his request, the Jesuits designed and built an imperial palace near Peking replete with European-style fountains. In addition, they made clocks, mechanical toys,

${ }^{45}$ Catherine Jami, The Emperor's New Mathematics: Western Learning and Imperial Authority During the Kangxi Reign 1662-1722 (Oxford: Oxford University Press, 2012), 33-4.

${ }^{46}$ Waley-Cohen, "China and Western Technology," 1529-30.

${ }^{47}$ Treutlein, "Jesuit Missions," 440.

${ }^{48}$ Waley-Cohen, "China and Western Technology," 1530-1.

${ }^{49}$ Ibid., 1532.

${ }^{50}$ Rowbotham, "Voltaire, Sinophile," 1054. 
glass, furnaces, hydraulic machinery, and devices for electroconvulsive shock treatment. ${ }^{51}$ It would appear, however, that practical technologies had more of an interest to the Chinese than did mathematical theory. One of the early translations into Chinese was the first six books of Christopher Clavius' Euclidis Elementorum libri XV(1574). Yet it appeared to have little impact on the Chinese use of geometry or their mathematical thinking; the remaining parts of Euclid were not translated into Chinese until $1851 .{ }^{52}$ Moreover, with only a few exceptions such as artillery and cartography, the Chinese appeared to have little in-depth interest in the Jesuit scientific and technological lessons, and virtually nothing spread through Chinese society at large.

\section{Leibniz and the Characteristica Universalis}

The Jesuits were certainly aware of the arguments being used back in Europe that the application of scientific methods to ancient Chinese history could be used to discount the accuracy of the biblical chronology. That approach, however, did not go unanswered by a group of Jesuits and their fellow travelers who became known as the Figurists. Interested in reconciling contradictions between the Chinese historical record and the biblical accounts, the Figurists conjectured such possible connections as, for example, the ancient Chinese being a lost tribe of Israel. Most intriguing was the support provided to the Figurists by Gottfried Leibniz. His stature was sufficient to influence the debate.

In a 1697 letter to the Electress Charlotte Sophia (1668-1705), Leibniz stated: "I shall have to post a notice on my door: Bureau of information for Chinese knowledge." ${ }^{33}$ Although this might have been considered boasting for some, for Leibniz it was accurate. Not only was he a leading intellect of the Enlightenment, he was undoubtedly also one of the best informed on China. Leibniz approached the study of China methodically and wrote two significant tracts on China: in 1697 Novissima Sinica (Recent News from China) which covered his correspondence on a number of topics with the Jesuits, and in 1713 Discours sur la théologie naturelle des Chinois (Discourse on the Natural Theology of China) which addressed Chinese philosophy. While Voltaire, whose writings on China were "scattered and unsystematic," sought transformation of the existing order, Leibniz sought universal principles of harmony that would transcend religions, politics, and cultures. ${ }^{54}$ Leibniz was a Lullist who followed the teachings of the

\footnotetext{
51 Waley-Cohen, "China and Western Technology," 1533.

52 Swetz, "Leibniz, the Yijing," 278.

53 Gottfried Wilhelm Leibniz, cited in "The Impact of Confucianism on Seventeenth Century Europe" by Arnold H. Rowbotham, The Far Eastern Quarterly 4, no. 3 (1945): 224-42, on 233.

${ }^{54}$ Clarke, Oriental Enlightenment, 47.
} 
Spanish Franciscan, Raemon Lull (1232-1316), and sought a universal language which would unite the Jewish, Christian, and Muslim mono-theistic faiths. ${ }^{55}$

If the Enlightenment was a period of the mathematization of nature, it was also a period of the mathematization of God. Leibniz, as did other theologians and philosophers of the time, believed that God was the supreme mathematician and that understanding nature meant decoding the mathematical precepts forming the foundation of the universe. Leibniz, who believed the key lay in binary mathematics, thought that the connection was not only metaphysical, but was also theological. "Creation was creation ex nibilo, creation out of nothing: the primary void was represented by 0 and the Creator God by 1 , and the forming of the cosmos resulted from a coming together of 1 and $0 .{ }^{56}$ For Leibniz, the key that seemed to provide the binary solution for the characteristica universalis was the ancient Chinese Book of Changes, or Yijing.

Although he corresponded regularly with the Jesuits in China and met with several during their return trips to Europe, Leibniz formed the closest intellectual relationship with Father Joachim Bouvet who was also interested in numerology and the search for a universal science. During the course of their correspondence, Leibniz wrote of his binary theory to Bouvet who immediately connected it with the broken and solid lines of the 64 hexagrams in the Yijing and so informed Leibniz. The idea, according to Joseph Needham, that the Chinese hexagrams and binary mathematics were related, was that of Bouvet rather than Leibniz. "Bouvet had brought the Book of Changes to Leibniz's attention in 1698, but it was not until Leibniz had sent him a table of his binary numerals in April 1701 that the identity with the hexagrams was realized." ${ }^{57}$ Leibniz was delighted that the Yijing appeared to mirror his own binary arithmetic, and speculated that Fuxi, the purported Chinese progenitor, had created the trigrams based upon the Christian Genesis narrative. ${ }^{58}$ While Leibniz thought he had discovered the key to the universal language, Bouvet concluded that Fuxi was the direct recipient of divine revelation..$^{59}$ In 1703 Leibniz presented a paper at the French Académie des Sciences (Academy of Sciences) in which he outlined his theory. It was, of course, the vehicle of the Chinese Other that permitted Leibniz to demonstrate this relationship between science and religion. As Leibniz wrote:

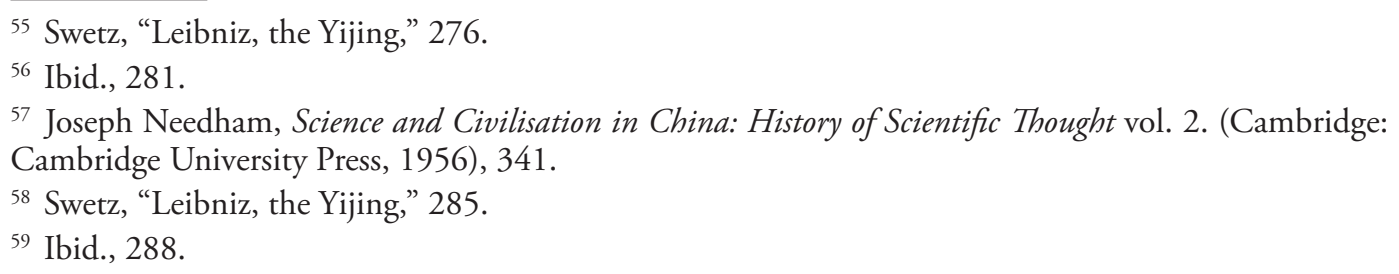


The substance of the ancient theology of the Chinese is intact and, purged of additional errors, can be harnessed to the great truths of the Christian religion. Fohy [Fuxi], the most ancient prince and philosopher of the Chinese, had understood the origin of things from unity and nothing, i.e., his mysterious figures reveal something of an analogy to Creation, containing a binary arithmetic (and yet hinting at greater things) that I rediscovered after so many thousands of years, where all the numbers are written by only two notations, 0 and $1 .^{60}$

Leibniz believed that "the ancient Chinese have surpassed the modern ones in the extreme, not only in piety (which is the basis of the most perfect morality) but in science as well." ${ }^{61}$ But, of course, it was the culturally superior Europeans that were duty-bound to recover the ancient knowledge that later Chinese had subsequently lost. For all his brilliance, Leibniz set himself a difficult task in trying to reconcile Eastern and Western civic thought, a rapidly modernizing science, and an evolving view of God and the Church. Needham saw in Leibniz a "Buddhist speculation seen through a Neo-Confucian glass, yet meeting (mirabile dictu) with the experimental verifications seen through the microscope by Leeuwenhoek and Swammerdam." ${ }^{62}$ Perhaps an insurmountable intellectual task even for Leibniz.

While Leibniz-the-Sinophile was clearly enamored of the potential connection between the Yijing and binary mathematics, Leibniz-the-European believed in the inherent superiority of European culture. According to Leibniz, "the Chinese lost the significance of these Cova or Lineations of Fohy [Fuxi], perhaps more than 1000 years ago. . . It is necessary that their true explanation now come to Europeans." ${ }^{63}$ Leibniz was not alone in his chauvinism. In 1705, Wilhelm Tentzel, editor of the scholarly journal Curieuse Bibliothec, trumpeted that "the Chinese had lost the true meaning of the hexagrams and that a European genius had to rediscover the knowledge for them." ${ }^{64}$ The genius, of course, being Leibniz.

So, what did the Chinese Other ultimately provide for Leibniz in his quest for universality? First, it provided an ancient language that he believed more natural than the alphabetic European languages, that could even potentially pre-date Babel, and that might even be the original human tongue. Second, it confirmed his belief that God was a mathematician and that the numerology of the Yijing would help him to find the binary foundation of a universal science. Leibniz felt strongly that there was no coincidence. The trigrams of the Chinese Yijing and the binary mathematics of a Christian god must share a common origin.

${ }^{60}$ Gottfried Wilhelm Leibnitz, Writings on China, trans. Daniel J. Cook and Henry Rosemont, Jr (Chicago: Open Court, 1998), 73.

${ }^{61}$ Ibid., 132-4.

62 Needham, Science and Civilisation vol. 2, 499.

${ }^{63}$ Leibniz in "Leibniz, the Yijing" by Swetz, 286-7.

${ }^{64}$ Tentzel in "Leibniz, the Yijing" by Swetz, 289. 


\section{The human sciences and the Chinese other}

As a logical extension of the Enlightenment's self-perceived manifestation of rationality in all things, the seeds of the modern social sciences were sown. Particular emphasis was given to application of rational principles to human economic and political interactions. As in other areas of the Enlightenment, China served as an allegorical tool of convenience to illuminate both the perfect and imperfect elements of European economics and politics.

In the newly developing economic sciences, China was simultaneously offered as an example of Enlightened laissez-faire economics, ${ }^{65}$ but also criticized for the restrictive effects of its Canton system of trading. ${ }^{66}$ Nevertheless, it is clear that China's economic customs were given broad consideration. In France, the Physiocrat François Quesnay (1694-1774) explained in 1758 in Tableau économique (Economic Table) that agriculture was the primary source of a country's wealth. Prefiguring Adam Smith (1723-1790), Quesnay extolled the virtues of a free marketplace based on an agrarian economy that largely mirrored that of China. As a result, Quesnay was referred to as the European Confucius. ${ }^{67}$ Such was the influence of the Physiocrats that, based on the Chinese tradition whereby the emperor every spring began the planting season by symbolically plowing the first furrows, Louis XIV briefly adopted the same practice in France. ${ }^{68}$ Anne-Robert-Jacques Turgot (1727-1781), a key government official in pre-revolutionary France, was sympathetic to the Physiocrat arguments and interested in the reports from China. Taking what would be considered a modern scientific approach to governmental management of the French economy, Turgot gave two Chinese students studying in France a list of 52 questions that they were to answer on their return to China, including whether Chinese farmers owned their land, the number of merchants, the amount of rice consumed, the price of grain and whether it was sold by measure or weight, techniques for textile manufacturing, and types of soil, minerals and clay. ${ }^{69}$ Although it is not clear whether the Wealth of Nations (1776) simply predicted the economic path that Europe was already inevitably traveling or whether his treatise fashioned an economic structure that might not otherwise have existed, Adam Smith was arguably influenced by what he knew of China. ${ }^{70}$ Yet the Chinese model was not a perfect paradigm for Smith for whom the nascent industrialization of Europe supplanted the Physiocrats' Chinese agrarian utopia.

\footnotetext{
${ }^{65}$ Davis, "China, the Confucian Ideal," 546.

66 Waley-Cohen, "China and Western Technology," 1543.

${ }^{67}$ Clarke, Oriental Enlightenment, 49.

68 Ibid., 50.

${ }^{69}$ Davis, "China, the Confucian Ideal," 539-40.

70 William W. Lockwood, "Adam Smith and Asia," The Journal of Asian Studies 23, no. 3 (1964): 34555 , on 349 .
} 
For Quesnay and other French Sinophiles, the Jesuit descriptions of Emperor Kangxi seemed to match their view of an enlightened despot. During the height of the Jesuit activities in China, these reports invariably described an agrarian state overseen by a virtuous despot who ruled through a meritocracy —all situated in a rational social ethic with no need for Christianity. ${ }^{71}$ Treatises such as Quesnay's 1767 Le despotisme de la Chine (The Despotism ofChina), based upon Jesuit sources, cited China as a model of the rational autocracy, and provided the philosophes a political lever to criticize the reality in Europe. ${ }^{72}$ Such tropes were not confined to France. In 1730 Christian Wolff (1679-1754), a famous protégé of Leibniz, delivered an address at Marburg in which he cited China as an example of enlightened despotism. ${ }^{73}$ However, Wolff simultaneously praised the much more advanced state of European physics and mathematics. ${ }^{74}$ Isaac Vossius (1618-1655) praised Chinese science, technology, and medicine and attributed their successes to the fact that they had approached closer to achieving a Platonic Republic than had the Europeans. ${ }^{75}$

Given the philosophes' mission to transform the government, morality, and religion of eighteenthcentury France, the Chinese Other provided fertile ground for their obliquely directed criticisms. Voltaire, ever searching for means to criticize the existing French order, defended the apparent absolutism of the Chinese emperor, insisting that he was a despot in form only, and that he manifested the ideal characteristics of the emperor-philosopher ${ }^{76}$ Necessitated by his personal ideological motivations, Voltaire's naive praise of Emperor Qianlong, Kangxi's grandson, was predicated on the inappropriately favorable reports of the Jesuits as well as the tendency of official Chinese proclamations to include glowing statements of a utopian moral ethic that, in reality, could never correspond to the actual conditions in China. ${ }^{77}$ Looking closer to home, while Voltaire praised the English parliament, he was concerned that it diminished the powers properly due the king; consequently, he was more comfortable with the Chinese system which had an absolute monarch supported by a rationally selected class of trained mandarins - all free of Christian religious bias. For Voltaire, China combined the virtues of the French absolute monarchy and the English constitutional government. ${ }^{78}$ Quesnay was also a great supporter of the Chinese system with its exacting education of a class of public servants who were competitively selected. ${ }^{79}$ While the Chinese governmental model was obviously not

\footnotetext{
${ }^{71}$ Wakeman, "The Chinese Mirror," 209.

72 Clarke, Oriental Enlightenment, 49.

${ }^{73}$ Lach, "China and the Era of the Enlightenment," 568.

${ }^{74}$ Ibid., 574.

75 Israel, Enlightenment Contested, 641.

${ }^{76}$ Rowbotham, “Voltaire, Sinophile," 1054.

77 Ibid., 1055.

${ }^{78}$ Ibid.

79 Davis, "China, the Confucian Ideal," 545.
} 
adopted in Europe, the Chinese example influenced the civil service competitive entrance examination systems of both France and Britain. ${ }^{80}$

Finally, even the American founding fathers were cognizant of the Chinese model. Benjamin Franklin (1706-1790), in the Preface of the first volume of Transactions of the American Philosophical Society, suggested that the economy of America could be better developed by introduction of technology developed in Asia: "And could we be so fortunate . . a as to introduce the industry of the Chinese, their arts of living and improvements in husbandry, as well as their native plants, America might in time become as populous as China." ${ }^{81}$ Although the Philadelphia society did not address the topic in its first edition as Franklin suggested, in 1783 Franklin did include a note in the Transactions on the benefits of China's technique for manufacturing large sheets of paper. ${ }^{82}$

\section{A sense of missing progress}

The Chinese were clearly interested in European science and technology. However, each is typically embedded within a set of social values. When advances in science and technology were contingent upon the importation of western cultural values, there was historic Chinese resistance. The Enlightened West began to interpret the Chinese disinterest in incorporating the European cultural context which fostered its science and technology "as evidence of an entire mental attitude: an ingrained xenophobia and a concomitant resistance to progress. In the Age of Progress, such an attitude led automatically to the assumption that the Chinese were inferior beings." ${ }^{83}$ And yet, there was occasional anecdotal evidence available to the Europeans that supported a Chinese sense of advancement. In the mid-1780s, Jean-Baptiste Grosier reported a gruesome notion of progress:

There is a mention in history books of the governor of a province who had the abdomen opened of forty villainous men who had themselves opened the bellies of pregnant women and some children too, then he employed several painters to make accurate drawings of their intestines in the presence of learned physicians who were authorized to instruct the torturers on where to make their cuts and so to profit from the just torture of these men for the sake of progress in medical science. $^{84}$

If there was reluctance on the part of the Chinese to absorb the Western trappings of progress, it may have been, in part, due to the manner in which the Europeans decided to share information.

${ }^{80}$ Clarke, Oriental Enlightenment, 49.

${ }^{81}$ Benjamin Franklin, 1964, cited in Lockwood, "Adam Smith and Asia," 348-9.

82 Lockwood, "Adam Smith and Asia," 349.

83 Waley-Cohen, "China and Western Technology," 1544.

${ }^{84}$ Grosier, The World of Ancient China, 85. 
Western inconsistencies may have undermined not only China's scientific progress, but also its perception of the accuracy of Europe's science. For example, the Church placed restrictions on the early missionaries that barred revelations of the complete discoveries by Copernicus and Galileo. When the complete information did finally reach China, the mandarins were skeptical because it contradicted earlier reports. ${ }^{85}$ In another instance, the ability of science to adapt, sometimes slowly, its theories to new empirical information created a problem when the Jesuits introduced the Aristotelian elements (earth, water, fire and air) into China-roughly equivalent to those in China (wood, fire, earth, metal and water)—only to be told a half century later that the theory was wrong. ${ }^{86}$

As the end of the Enlightenment era drew near, the role of the Chinese Other was transformed. Although Europe's cultural insecurity was demonstrated by its continuing need to validate its own superiority, both the nature and the object of its reflective calibration changed. A sense of progress became a benchmark against which all else was measured. The Chinese despots that had previously been enlightened were now simply tyrants. China's previously remarkable stability became stagnancy. The disenchantment with China's progress, and the responsibility of Europe to bestow its cultural munificence, was captured in 1794 by Marquis de Condorcet (1743-1794): the Chinese "need only assistance from us to become civilized . . . and who for so many centuries have cried out to be liberated." 77

Ironically, the previous European enthrallment with China's ancient heritage and cultural stability was transformed into a sense of regression. Just as the Renaissance had transitioned to a sense of scientific discovery when compared to the Middle Ages preoccupation with recovery of Greek wisdom, the Enlightenment ceased to attach importance to the purported rationality of China's ancient Confucian roots as being in contradiction to the eighteenth-century idea of progress. ${ }^{88}$ Even Voltaire, who never ceased to be a Sinophile, was forced to reconcile the lack of continuous progress in China's arts and sciences by maintaining that the Chinese developed art and science to provide them the maximum human happiness and did not feel it necessary to go further. ${ }^{89}$ What was becoming increasingly evident was that the East to West flow of technological invention of the first millennium had reversed by the seventeenth century. ${ }^{90}$

\footnotetext{
85 Waley-Cohen, "China and Western Technology," 1535.

${ }^{86}$ Needham, Science and Civilisation vol. 2, 294.

${ }^{87}$ Antoine-Nicolas Condorcet, Sketch for a Historical Picture of The Progress of the Human Mind, trans. June Barraclough (Westport CN: Greenwood Press, 1955), 177-8.

${ }^{88}$ Rowbotham,"Voltaire, Sinophile," 1057.

89 Ibid., 1060.

${ }^{90}$ Needham, Science and Civilisation vol. 2, 516.
} 


\section{The end of Sinophilia}

By the time of the French Revolution, the zenith of Enlightenment Sinophilia had passed. With Europe's economic growth, the acceleration of technological innovations, and the weakening of the aristocracy and the Church, the growing sense of progress meant a cultural devaluation of the past-whether European or Chinese. "The once prevalent conception that classical Oriental antiquity represented a lost Golden age was widely attacked as nostalgic and running contrary to natural law of evolution. Chinese antiquity, which had previously been regarded as a virtue, had become a vice." ${ }^{91}$ While familiarity may not necessarily breed contempt, in the case of Enlightenment China, it certainly meant, at a minimum, disenchantment. That does not mean that Europe had lost its need for an Other; it simply looked elsewhere. A significant part of the European disillusionment with China resulted from a change in values-European values. "The meritocracy now seemed to be composed either of corrupt customs officials or of effeminate literati who spent all their time memorizing irrelevant classics. Enlightened emperors appeared to be oriental despots, applying barbaric tortures to kowtowing sycophants." ${ }^{2}$ Guillaume Thomas François Raynal (1713-1796), in his 1770 Histoire philosophique et politique des établissements et du commerce des Européens dans les deux Indes (A philosophical and political history of the settlements and trade of the Europeans in the East and West Indies), praised the use of the "thrifty and intelligent" Chinese agricultural laborers imported into the Philippines. ${ }^{93}$ Yet in his later writings he concluded that China was not to be admired and that its rulers were to be considered despotic. ${ }^{94}$ An abrupt about-face, but typical of many during the European Enlightenment.

A few of the leading intellects of the Enlightenment had never fallen under the Sinophilia spell. Although overshadowed by Voltaire, Montesquieu had consistently maintained that the Oriental despots were, in fact, corrupt tyrants, and used the Oriental Other in his Persian Letters to indirectly attack Louis XIV. ${ }^{95}$ Jean-Jacques Rousseau (1712-1778) believed that: "there is in Asia a vast country in which the sciences are a passport to the highest positions in the state. If the sciences really purified morals ... if they really inspired courage, then the people of China would assuredly be wise, free, and invincible. But as a matter of fact, there is no sin to which they are not prone, no crime which is not common amongst them." ${ }^{\prime 6}$ Rousseau's comment is noteworthy not only for its condemnation of Chinese morals, but also for concluding that

\footnotetext{
${ }^{91}$ Hung "Orientalist Knowledge," 263-64.

92 Wakeman, "The Chinese Mirror," 209.

${ }^{93}$ Guillaume Thomas Raynal, A History of the Two Indies: A Translated Selection of Writings from Raynal's Histoire philosophique et politique de établissements de Européens dans les Deux Indes, ed. Peter Jimack (Aldershot, UK: Ashgate, 2006), 64.

${ }^{94}$ Peter Jimack in Introduction to $A$ History of the Two Indies by Raynal, xvii.

95 Hung, "Orientalist Knowledge," 262.

${ }^{96}$ Jean-Jacques Rousseau, cited in Davis "China, the Confucian Ideal,” 538.
} 
morals cannot be purified by science- the very tool that was being used against the perceived immorality of rule by the European aristocracy and the Church.

Despite the influence of Voltaire, Leibniz and other Sinophiles, the continuing critique of China by other influential intellects such as Diderot, Condorcet, Helvetius, and Kantsome of whom had originally been avid Sinophiles—-took its toll as well. ${ }^{77}$ While China was increasingly characterized as despotic, backward, and corrupt, many of the philosophes touted the new Other to be the pure, natural Noble Savage, especially that of the New World. This criticism was also compounded by the 1748 discovery of the ruins of Pompeii that reawaked Hellenistic sentiments that cast comparative suspicions on China's wisdom, government, morality and religious practices. ${ }^{98}$

The Jesuits, who had been a consistent source of glowing reports about China, lost a considerable amount of their influence with the Chinese court after a papal mission in 17051706 seemed to confirm Chinese suspicions of the Catholic Church's very terrestrial political ambitions when it attempted to extend Rome's authority over Chinese Christians. As a result, both Emperor Yongzheng (1723-1735) and his son Emperor Qianlong barred Christian missionaries from the provinces, but nevertheless took no significant steps to purge China entirely of Christianity. ${ }^{99}$ For more than a century, the Jesuits had had a monopoly on reporting from China and had reported consistently in a positive way. However, with the arrival of the rival Franciscan and Dominican orders, the establishment of foreign embassies, and the near invasion of commercial interests, that all changed. Juan Bautista Morales (1597-1664), one of the first Dominican missionaries in China in 1633, returned to Rome in 1643 and attacked the Jesuit approach. ${ }^{100}$ With a loss of its information control, the estrangement from the Chinese imperial court, the besiegement by the Vatican, and a shifting popular opinion in France, the Jesuits joined the surge in Sinophobia. "In the last Jesuit writings on China, published between 1776 and 1814, Confucius was no longer portrayed as an elegant gentleman standing in front of shelves of books, as he had been represented in earlier Jesuit books. Instead, he was presented as a distressingly ugly man with a pointed head, very dark skin, a straggly beard, and very long fingernails." ${ }^{101}$ In 1773, Pope Clement XIV (1705-1774) abolished the Jesuit order. It was not until 1814 that Pope Pius VII (1742-1823) reversed this suppression of the order.

At the beginning of the Enlightenment and for much of its duration, China was indeed the ideal Other. It was distant and its profound difference facilitated a Rorschach-like reflection of European values that was perfect for ideologically motivated interpretations. Moreover,

\footnotetext{
${ }^{97}$ Hung, "Orientalist Knowledge," 262.

${ }_{98}$ Clarke, Oriental Enlightenment, 52.

${ }^{99}$ Waley-Cohen, "China and Western Technology," 1532-3.

${ }^{100}$ Standaert, "Christianity Shaped by the Chinese," 572.

${ }^{101}$ Hung, "Orientalist Knowledge," 262.
} 
it not only had a technological base that was initially the equal to that of fifteenth-century Europe, a highly developed and self-sufficient agrarian economy, and a secular civic ethic, it had accomplished all this without the need for either Christianity or even a deity. Yet Europe's eventual disenchantment was only with China, not with the idea of an Other. China, as the Oriental Other, was replaced by India.

Where the Confucian logic of China had ensnared the rationalists of the eighteenth century, the Buddhist and Hindu mysticism of Oriental India beckoned the romantics of the nineteenth century. ${ }^{102}$ India was held out as epitomizing the romantic image of the childhood of humanity, an age of innocence, religiosity and closeness to nature. Moreover, as the British began to control India, the flow of publicly available information increased. Paralleling the dialogue with China a hundred years earlier, the Christians began to argue that the very antiquity of Hinduism and its resemblance to Christianity proved the divine origin of the Bible. ${ }^{103}$ The dynamics of the intellectual exchange between Europe and India were very different from that between Europe and China.

Not only had the cultural mirror changed, but the Europe that was being reflected had also changed. As a medium of exchange, science and technology became much less important as a mechanism for eroding the power of the aristocracy and the Church. First, the British were the European power in India. Henry VIII (1491-1547) had already thrown off the Catholic Church, and the power of the aristocracy was firmly countered by an active parliament. Second, where China was recognized to have made innovative contributions in science and technology, India was relatively backward technically; as a mechanism of cultural exchange, science and technology became relatively less important. Third, China's value as an Other was in large part predicated upon its independence from European dominance, a lack of a deity and an advanced culture development. India, however, was a British colony which was to be exploited in a much more straightforwardly material fashion. Moreover, not only was India theistic, it was also polytheistic; there appeared to be a god for every occasion. Finally, the cultural dynamics within Europe had changed its priorities. The French Ancien Régime was gone. Industrialization and the competition for colonial expansion absorbed much of the intellectual capital of Europe. Not only had the Oriental Other mirror changed, but the image that Europe wished to see in the mirror had also changed.

\section{Competing interests}

The author has declared that no competing interests exist.

${ }^{102}$ Lach, "China and the Era of the Enlightenment," 220.

${ }^{103}$ Chen Tzoref-Ashkenazi, "India and the Identity of Europe: The Case of Friedrich Schlegel," Journal of the History of Ideas 67, no. 4 (2006): 713-34, on 714-6. 